\title{
The Effect of Erector Spinae Plane Block on Postoperative Pain Following Laparoscopic Cholecystectomy: A Randomized Controlled Study
}

\author{
Can Aksu $\odot$ \\ Alparslan Kuş $\odot$ \\ Hadi Ufuk Yörükoğlu ๑ \\ Cennet Tor Kılıç $\odot$ \\ Yavuz Gürkan ๑
}

\author{
Erektor Spina Plan Bloğunun Laparoskopik \\ Kolesistektomi Sonrası Postoperatif Ağrı Üzerine \\ Etkisi: Randomize Kontrollü Çalışma
}

\begin{abstract}
Objective: Erector spinae plane block (ESP) is a novel technique for postoperative pain management. Primary aim of this study is to evaluate efficacy of ultrasound-guided ESP for providing postoperative analgesia in laparoscopic cholecystectomy (LC) procedures.

Methods: Forty-six ASA I-II patients aged 20-70, who were scheduled to undergo elective LC were included in the study. Patients were randomized into two groups as ESP and Control group. Patients in the ESP group received ultrasound (US)- guided ESP block with $20 \mathrm{ml} 0.25 \%$ bupivacaine. An intravenous patient-controlled analgesia device containing morphine was provided for all the patients in both groups. Morphine consumptions at postoperative $24^{\text {th }}$ hour and postoperative numeric rating scale (NRS) scores for pain were recorded.

Results: Mean morphine consumptions at postoperative $24^{\text {th }}$ hour were $7.5 \mathrm{mg} \pm 5.8$ in the ESP group while it was $13.2 \pm 5.6 \mathrm{mg}$ in the control group $(p<0.01)$. There was also a significant difference between the groups as for NRS scores at $12^{\text {th }}$ and $24^{\text {th }}$ hours ( $p=0.016, p=0.003$ respectively). None of the patients in the ESP group complained about shoulder pain; but in the control group 9 patients reported shoulder pain.

Conclusion: This study has shown that ESP block at T8 level has reduced the opioid consumption and showed a significant analgesic effect in patients undergoing $L C$.
\end{abstract}

Keywords: Erector spinae plane block, laparoscopic cholecystectomy, postoperative pain, opioid consumption

öz

Amaç: Erektör spina plan (ESP) bloğu, postoperatif ağrı yönetimi için yeni bir tekniktir. Bu çalışmanın ilk amacı, ultrason eşliğinde uygulanan ESP'nin, laparoskopik kolesistektomide postoperatif analjezi sağlamak açısından etkinliğini değerlendirmektir.

Yöntem: Elektif laparoskopik kolesistektomi operasyonu planlanan 20-70 yaşında 46 ASA I-II hasta çalışmaya dahil edildi. Hastalar ESP ve Kontrol grubu olmak üzere 2 gruba randomize edildi. ESP grubundaki hastalara $20 \mathrm{ml} \% 0.25$ bupivakain ile ultrason eşliğinde ESP bloğu yapıldı. Her iki gruptaki hastalara operasyon sonrası morfin içeren hasta kontrollü analjezi cihazı temin edildi. Hastaların postoperatif 24. saatteki morfin tüketimleri ve postoperatif numerik ağrı skalaları (NRS) kaydedildi.

Bulgular: Postoperatif 24. saatte ESP grubunda ortalama morfin tüketimi $7.5 \pm 5.8 \mathrm{mg}$ iken kontrol grubunda $13.2 \pm 5.6 \mathrm{mg}(p<0.001)$ idi. Ayrıca gruplar arası postoperatif 12 . ve 24. saatlerdeki NRS skorlarında da anlamlı fark gözlendi ( $p=0.016$ ve $p=0.003$ ). ESP grubundaki hastalarda omuz ağrısı gözlenmezken kontrol grubunda 9 hastada omuz ağrısı gözlendi.

Sonuç: Bu çalışma ultrason eşliğindeki ESP bloğun laparoskopik kolesistektomi operasyonlarında morfin tüketimini azalttığını ve etkin analjezi sağladığını göstermektedir.

Anahtar kelimeler: Erektör spina plan bloğu, laparoskopik kolesistektomi, postoperatif ağrı, opioid tüketimi
Alındığı tarih: 19.12 .2018

Kabul tarihi: 16.01.2019

Yayın tarihi: 31.01.2019

Can Aksu

Kocaeli Üniversitesi Tıp Fakültesi Anesteziyoloji ve Reanimasyon Anabilim Dalı,

Umuttepe Kocaeli - Türkiye

dr.aksu@gmail.com ORCID: 0000-0002-4389-4257

A. Kuş 0000-0001-6381-6371 H.U. Yörükoğlu 0000-0001-7572-1580 C. Tor Kılıç 0000-0002-6596-1799 Y. Gürkan 0000-0002-2307-6943

Kocaeli Üniversitesi Tıp Fakültesi, Anesteziyoloji ve Reanimasyon Anabilim Dalı, Kocaeli - Türkiye 


\section{INTRODUCTION}

Laparoscopic cholecystectomy (LC) technique is becoming more and more popular than open cholecystectomy as it leads to lesser surgical trauma, better tissue healing and also faster recovery. Even though it is a minimally invasive surgery; pain after LC still stands as a problem to solve.

Postoperative pain after LC is related to many etiologies as surgical manipulations, visceral pain, subdiaphragmatic irritation and indwelling abdominal trocars. There is also a somatic component due to indwelling abdominal trocars. In addition, many of the patients complain about shoulder pain ${ }^{(1)}$.

Erector spinae plane (ESP) block is a newly defined block technique that is being increasingly used for postoperative analgesia. Although this block is relatively simple to learn and when applied properly, may have fewer side effects than epidural anesthesia and paravertebral blocks, its use and efficacy in providing postoperative analgesia for different indications have not been studied till now. Many case reports for use of ESP block are available in the literature ${ }^{(2,3)}$. A recently published study of Tulgar et al. ${ }^{(4)}$ is the first randomized controlled trial (RCT) about ESP use in LC. There is still a need for more data for its clinical relevancy. This RCT was designed to assess the efficacy of the ESP block for analgesia in patients undergoing LC. Our primary aim is to compare the cumulative morphine consumption within the first 24 hours after surgery. Comparing pain scores, opioid-related side effects, nausea and vomiting were the secondary end points.

\section{MATERIAL and METHOD}

This prospective randomized controlled study was done after obtaining ethics committee's permission (KIA 2017-349/28.11.2017) and written informed consent of the patients between February and April 2018. The study was registered prior to patient enrollment with clinicaltrials.gov (NCT03420703).

Patients with ASA physical status I-II, aged 20-75 years and scheduled for elective laparoscopic cholecystectomy were included in the study. Patients with ASA physical status III-IV, obesity (body mass index $>35 \mathrm{~kg} \mathrm{~m}^{-2}$ ), infection of the skin at the site of needle puncture area, with known allergies to any of the study drugs, coagulopathy, and also recent users of opioids were excluded from the study.

Randomization was performed according to computer-generated random number tables, and allocation to treatment group was done using the sealed opaque envelope technique. According to randomization, patients were divided into two groups to receive either ultrasound-guided erector spinae plane block (ESP group) or no intervention (Control group).

\section{General Anesthesia}

All patients were premedicated using midazolam $0.03 \mathrm{mg} \mathrm{kg}^{-1}$ iv upon arrival to the preoperative holding area. In the operating room all patients had received standardized monitoring which included $\mathrm{SPO}_{2}, \mathrm{ECG}$, non invasive blood pressure monitoring.

Propofol (2-3 $\left.\mathrm{mg} \mathrm{kg}^{-1}\right)$ and fentanyl $\left(2 \mathrm{mg} \mathrm{kg}^{-1}\right)$ iv were used for general anesthesia induction. Rocuronium (0.6 mg kg-1 IV) was administered for tracheal intubation. Desflurane in combination with nitrous oxide in oxygen with a ratio of 2:1 in $3 \mathrm{~L}$ of fresh gas flow was used for the maintenance of general anesthesia. At the end of the surgery, all of the patients received paracetamol $1 \mathrm{~g}$ IV and tramadol $100 \mathrm{mg}$ as a standard for postoperative analgesia. For preventing postoperative nausea and vomiting ondansetron ( $8 \mathrm{mg} / \mathrm{M}$ ) was also administered to all patients.

At the end of the surgery neuromuscular reversal was provided with administration of neostigmine $(0.05 \mathrm{mg}$ $\left.\mathrm{kg}^{-1} \mathrm{IV}\right)$ and intravenous atropine $\left(0.02 \mathrm{mg} \mathrm{kg}^{-1}\right)$.

\section{ESP Technique}

Following sedation and standardized monitoring, ESP block was performed at the preoperative block area. All blocks were performed approximately 20 min before induction of general anesthesia. Povidone- iodine $10 \%$ was used for skin preparation. Probe was covered with a sterile cover. The same two anesthesiologists (YG, CA), experienced in USguided regional anesthesia techniques, performed 
C. Aksu ve ark., The Effect of Erector Spinae Plane Block on Postoperative Pain Following Laparoscopic Cholecystectomy: A Randomized Controlled Study

all blocks. Esaote My Lab 6 US machine (Florence, Italy) with large bandwidth, and a multifrequency convex probe (1-8 $\mathrm{MHz}$ ) was used for performing the block. A 22G, $50 \mathrm{~mm}$, insulated facet type needle (BBraun Sonoplex, Melsungen, Germany) was used during all blocks. The blocks were performed with the patient in the prone position, at the T8 level using in-plane approach.

Convex probe was placed $2-3 \mathrm{~cm}$ lateral to the spine using a sagittal approach. After identification of erector spinae muscle and transverse processes, the needle was inserted deeply into the erector spinae muscle (Fig. 1). The needle was inserted via craniocaudal direction. As the rhomboid major muscle has its lower border at T5-6, in the ultrasonographic image, since only two muscles would be seen at this level, additional information is required so as to confirm the vertebral level. Correct position of the needle tip was confirmed with administration of $0.5-1 \mathrm{ml}$ of local anesthetic (LA), and $20 \mathrm{ml}$ of $0.25 \%$ bupivacaine was administered to perform ESP block. LA spread to both cranial and caudal directions was seen.

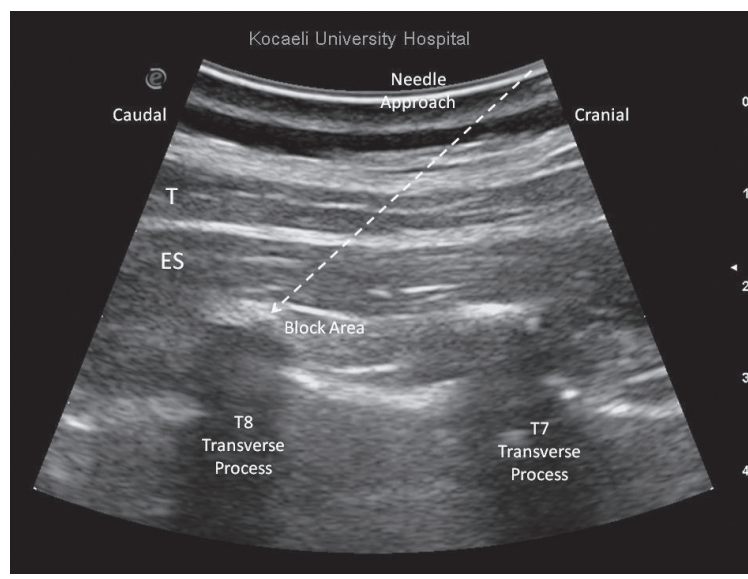

Figure 1. Ultrasound image of Erector Spinae Plane Block. T: Trapezius, ES: Erector Spinae

In the recovery room, all patients were given a patient-controlled analgesia device (PCA) containing morphine $0.5 \mathrm{mg} \mathrm{ml}^{-1}$, a set to deliver $1 \mathrm{mg}$ bolus dose of morphine up to at most $6 \mathrm{mg} / \mathrm{hr}$ with an 8 min lockout time. Cumulative morphine consumptions at postoperative $1^{\text {st }} 6^{\text {th }} 12^{\text {th }}$ and $24^{\text {th }}$ hours were recorded. Numeric rating scale (NRS) ranging from 0 (no pain) to 10 (worst imaginable pain) was used for pain assessments at $1^{\text {st }}, 6^{\text {th }}, 12^{\text {th }}$ and $24^{\text {th }} \mathrm{h}$ postoperatively. Patients were questio- ned for shoulder pain and the incidence of nausea and vomiting. A pain nurse blinded to the procedure did all data collection.

\section{Statistical Analyses}

A preliminary study in our clinic has shown that the mean $( \pm S D)$ morphine consumption in the postoperative $24 \mathrm{~h}$ was $14 \pm 4.4 \mathrm{mg}$. For $90 \%$ statistical power and an error of 0.05 , the sample size necessary to detect a $30 \%$ difference in postoperative morphine requirement using ESP compared to control group was 20 subjects per group. We included 25 patients in each group to compensate for patient dropouts.

All statistical analyses were performed using IBM SPSS for Windows ${ }^{\circledR}$ version 20.0 (SPSS, Chicago, IL, USA). Kolmogorov-Smirnov tests were used to test the normality of data distribution. Continuous variables were expressed as mean \pm standard deviation, median $\left(25^{\text {th }}-75^{\text {th }}\right.$ percentiles), and categorical variables were expressed as numerical values (percentages). Comparisons of normally distributed continuous variables between the groups were performed using Student's t test, and intergroup comparisons of non-normally distributed continuous variables were performed using the Mann Whitney $U$ Test. Comparisons of categorical variables between the groups were performed using the Fisher's Exact Chi Square test, Yates' Chi Square test, Monte Carlo Chi Square test. A two-sided $p$ value of $<0.05$ was considered statistically significant.

\section{RESULTS}

Forty-six patients were enrolled in the study (flow diagram). Demographical data and duration of surgeries were similar between the groups (Table I).

Table I. Demographic data

\begin{tabular}{lccc}
\hline & $\begin{array}{c}\text { ESP Group } \\
(\mathbf{n}=\mathbf{2 3})\end{array}$ & $\begin{array}{c}\text { Control Group } \\
(\mathbf{n}=\mathbf{2 3})\end{array}$ & $\mathbf{p}$ \\
\hline Age (year) & $49.26 \pm 14.18$ & $47.26 \pm 13.46$ & 0.626 \\
Weight $(\mathrm{kg})$ & $75.21 \pm 13.25$ & $75.69 \pm 13.77$ & 0.905 \\
Height $(\mathrm{cm})$ & $163.65 \pm 8.44$ & $164.08 \pm 8.92$ & 0.866 \\
BMI $\left(\mathrm{kg} \mathrm{m}^{-2}\right)$ & $28.05 \pm 4.41$ & $28.07 \pm 4.32$ & 0.989 \\
Sex $($ Female/Male) & $17 / 6$ & $16 / 7$ & 0.746 \\
ASA (I/II) & $13 / 10$ & $13 / 10$ & 1 \\
Duration of Surgery (min) & $75 \pm 12.79$ & $79.56 \pm 20.93$ & 0.377
\end{tabular}

Data were presented as mean \pm standart deviation or numbers. 
Mean morphine consumptions at postoperative $24^{\text {th }}$ hour were $7.5 \mathrm{mg} \pm 5.8$ in the ESP group while it was $13.2 \pm 5.6 \mathrm{mg}$ in the control group $(\mathrm{p}<0.01)$. Morphine consumptions at postoperative $6^{\text {th }}, 12^{\text {th }}$ and $24^{\text {th }}$ hours significantly decreased in the ESP group $(p=0.22, p=0.001, p<0.01$ respectively). Half of the patients in the ESP group (52\%) didn't use any dose of morphine after the postoperative $12^{\text {th }}$ hour while $3(13 \%)$ patients in the control group used morphin.

There was also a significant difference between the groups on NRS scores at $12^{\text {th }}$ and $24^{\text {th }}$ hours ( $p=0.016$, $\mathrm{p}=0.003$ respectively) (Table II). At postoperative $12^{\text {th }}$ hour $78.3 \%$ and at postoperative $24^{\text {th }}$ hour $82.6 \%$ of the patients were pain-free (NRS $=0$ ) in the ESP group while in the control group $43.5 \%$ and $43.5 \%$ of the patients were pain free at indicated postoperative time points.

Table II. Postoperative NRS scores and morphine consumptions in the first 24 hour

\begin{tabular}{lccc}
\hline & $\begin{array}{c}\text { ESP Group } \\
(\mathbf{n}=\mathbf{2 3})\end{array}$ & $\begin{array}{c}\text { Control Group } \\
(\mathbf{n}=\mathbf{2 3})\end{array}$ & $\mathbf{p}$ \\
& & & \\
\hline NRS scores & $2(0-4)$ & $2(2-4)$ & 0.742 \\
$1^{\text {st }}$ hour & $0(0-2)$ & $2(0-2)$ & 0.109 \\
$6^{\text {th }}$ hour & $0(0-0)$ & $1(0-2)$ & 0.016 \\
$12^{\text {th }}$ hour & $0(0-0)$ & $1(0-2)$ & 0.003 \\
$24^{\text {th }}$ hour & & & \\
Morphine consumption (mg) & $1(1-1)$ & $1(1-1)$ & 0.715 \\
$1^{\text {st }}$ hour & $4(2-6)$ & $5(4-8)$ & 0.022 \\
$6^{\text {th }}$ hour & $5(3-7)$ & $8(6-12)$ & 0.001 \\
$12^{\text {th }}$ hour & $5(4-8)$ & $12(10-16)$ & $<0.001$ \\
$24^{\text {th }}$ hour & & & \\
& & & \\
\hline
\end{tabular}

Data were presented as median (percentiles 25-75).

None of the patients in the ESP group complained about shoulder pain; but in the control group 9 patients reported about this type of pain $(p=0.003)$.

There were no significant difference between the groups as for incidence of postoperative nausea and vomiting ( $p=0.093$ and $p=0.284$, respectively). Three patients in the ESP group had postoperative nausea and all of the patients also had vomiting. In the control group 9 patients had nausea and 7 of them had also vomiting. Any preoperative or postoperative complications were not observed in both groups.

\section{DISCUSSION}

This study has shown that ESP block at the T8 level has significantly decreased the morphine consumpti- on at postoperative $6^{\text {th }}, 12^{\text {th }}$ and $24^{\text {th }}$ hours after LC. Decrease in total morphine consumption at postoperative 24 hours was $43 \%$ relative to the control group (Table 2). Our findings support the observations from previous reports ${ }^{(4-6)}$.

Type of pain after LC differs according to the applied open cholecystectomy technique as the main component of the pain changes from parietal to visceral. Also, patients complain about shoulder pain, which is secondary to diaphragmatic irritation caused by pneumoperitoneum.

Studies have been done to examine the effects of various analgesic modalities for postoperative analgesia in LC eg, use of non-steroidal anti-inflammatory drugs (NSAIDs); pre-emptive analgesic regimens; intraperitoneal local anesthetics; infiltration of the incision site with local anesthetics; and regional anesthesia techniques including thoracic epidural and paravertebral block techniques ${ }^{(7)}$. There were many controversial results in the literature about almost every method except regional techniques. Ahiskalioglu et al. ${ }^{(8)}$ reported NSAIDs as an analgesic for reducing all types of pain but contrarily Puolakka et al. ${ }^{(9)}$ has found NSAIDs ineffective in this type of surgeries. Liu et al. ${ }^{(10)}$ reported superior analgesia with incisional instillation of LAs while Hilvering et al. (11) reported no difference between placebo and infiltration.

Intraperitoneal instillation of LAs was popular in the past and has been studied by many practitioners ${ }^{(7)}$. Most commonly bupivacaine instillation was preferred but methods of LA instillation differed greatly including location and timing of instillations. Many studies with different outcomes could be found in the literature, but only a marginal effect of LA instillation derived from some poor-quality studies was shown in a recent Cochrane review ${ }^{(12)}$.

Epidural analgesia was proven to be successful for achieving postoperative analgesia in LC; but due to recommendations based on the principles of evidence-based medicine, it was not recommended for routine use because lack of evidence concerning rational cost-benefit ratio ${ }^{(7,13)}$.

Most recent and successful analgesia technique for 
C. Aksu ve ark., The Effect of Erector Spinae Plane Block on Postoperative Pain Following Laparoscopic Cholecystectomy: A Randomized Controlled Study

LC was found to be paravertebral block in the literature. Naja et al. ${ }^{(14)}$ reported that when used as complementary to general anesthesia, bilateral paravertebral block may improve postoperative pain relief. In another study of Naja et al. ${ }^{(15)}$ it was found that when bilateral paravertebral block performed prior to general anesthesia it could provide early discharge and better postoperative pain management. Even though paravertebral block was found to be adequate for this indication, due to the fact that it is an advanced technique which has the risk for serious complications, researchers are in the search of relatively safer and easier alternative techniques.

ESP is a newly defined, relatively safe and promising regional anesthesia technique. Exact mechanism and spread of this block are yet not defined clearly. For possible explanation, Forrero et al. (16) studied the spread of this block in cadavers and reported that the dye spread to both dorsal and ventral rami of spinal nerves, which cause a sensory blockade over the anterolateral thorax. Chin et al. ${ }^{(17)}$ reported a 7 level cranio-caudal spread of the LA with a single injection of 20-30 ml. In a recent magnetic resonance imaging and anatomical study, 2-5 level epidural and 5-9 level intercostal LA spread with ESP block was found ${ }^{(18)}$. This could explain the mechanism of this block but further studies with larger samples are needed to verify these findings.

There are many case reports in the literature about ESP use in different surgeries ${ }^{(2,3,19,20)}$. Hannig et al. ${ }^{(6)}$ reported ESP use for LC in adults and Aksu et al. ${ }^{(5)}$ reported its use in pediatric population for the same purpose. ESP was found to be successful for achieving postoperative analgesia in both reports. Recently published study of Tulgar et al. ${ }^{\left({ }^{4}\right)}$ has shown that ESP block with $20 \mathrm{ml} 0.375 \%$ bupivacaine significantly decreased NRS at rest within the postoperative first $3 \mathrm{~h}$ and also decreased total analgesia requirement in the postoperative $24 \mathrm{~h}$ relative to the control group. Our results showed similarity with these reports and confirmed that ESP block can decrease opioid requirements considerably. A mean morphine consumption of $7.5 \mathrm{mg}$ within $24 \mathrm{~h}$ in the ESP group is found to be significantly lower when compared to $13.2 \mathrm{mg}$ used in the control group.

Shoulder pain after LC could be seen in $30-50 \%$ of the patients most often on the right side ${ }^{(21)}$. It could be insignificant during the first postoperative hours, but increases thereafter to become the main complaint on the second day postoperatively ${ }^{(1)}$. Unlike other studies, in this study there was a significant difference between the groups as for the shoulder pain. None of the patients in the ESP group had complained about shoulder pain while $9(39 \%)$ patients in the control group complained of shoulder pain. ESP seems to be a promising method to cover up the analgesia of all components of postoperative pain in LC.

There were also some limitations and some unanswered questions. Due to the nature of the study, the patients could not be blinded to whether they had ESP block or not. Secondly a sensory testing for the mapping of block area has not been performed. Optimal volume and concentration of local anesthetic are still unknown. Also, the optimal time for block placement should be considered. We think these limitations could be the targets of future studies.

\section{CONCLUSION}

This study has shown that ultrasound- guided ESP block is effective for providing adequate analgesia following laparoscopic cholecystectomy and it also reduces opioid consumption. In parallel with this outcome, NRS scores and incidence of PONV significantly decreased. We think that, further studies evaluating and comparing the efficacy of different regional techniques and different doses of LAs are required to find the best possible analgesic technique for this type of surgery.

\section{REFERENCES}

1. Lee $\mathrm{DH}$, Song $\mathrm{T}$, Kim KH, Lee KW. Incidence, natural course, and characteristics of postlaparoscopic shoulder pain. Surg Endosc. 2018;32:160-5. https://doi.org/10.1007/s00464-017-5651-5

2. Aksu C, Gürkan Y. Ultrasound guided erector spinae block for postoperative analgesia in pediatric nephrectomy surgeries. J Clin Anesth. 2018;45:35-6. https://doi.org/10.1016/j.jclinane.2017.12.021

3. Cesur S, Ay AN, Yayik M, Naldan ME, Gurkan Y. Ultrasound-guided erector spine plane block provides effective perioperative analgesia and anaesthesia for thoracic mass excision: A report of two cases. Anaesth Crit Care Pain Med. 2018;52352-5568:30372-7. https://doi.org/10.1016/j.accpm.2018.01.002. [E-pub 
ahead of print]

4. Tulgar S, Kapakli MS, Şentürk O, Selvi O, Serifsoy TE, Ozer Z. Evaluation of ultrasound-guided erector spinae plane block for postoperative analgesia in laparoscopic cholecystectomy: A prospective, randomized, controlled clinical trial. J Clin Anesth. 2018;49:101-6. https://doi.org/10.1016/j.jclinane.2018.06.019

5. Aksu C, Gürkan Y. Ultrasound-guided bilateral erector spinae block could provide effective postoperative analgesia in laparoscopic cholecystectomy in paediatric patients. Anaesth Crit Care Pain Med. 2019;38:87-8.

https://doi.org/10.1016/j.accpm.2018.03.008. [Epub ahead of print]

6. Hannig KE, Jessen C, Soni UK, Børglum J, Bendtsen TF. Erector Spinae Plane Block for Elective Laparoscopic Cholecystectomy in the Ambulatory Surgical Setting. Case Rep Anesthesiol 2018;2018:5492527. https://doi.org/10.1155/2018/5492527

7. Barazanchi AWH, MacFater WS, Rahiri JL, Tutone $S$, Hill AG, Joshi GP; PROSPECT collaboration. Evidence-based management of pain after laparoscopic cholecystectomy: a PROSPECT review update. $\mathrm{Br} J$ Anaesth. 2018;121:787-803. https://doi.org/10.1016/j.bja.2018.06.023

8. Ahiskalioglu EO, Ahiskalioglu A, Aydin P, Yayik AM, Temiz A. Effects of single-dose preemptive intravenous ibuprofen on postoperative opioid consumption and acute pain after laparoscopic cholecystectomy. Medicine. 2017;96:8.

https://doi.org/10.1097/MD.0000000000006200

9. Puolakka P, Puura A, Pirhonen R et al. Lack of analgesic effect of parecoxib following laparoscopic cholecystectomy. Acta Anaesthesiol Scand. 2006;50:1027-32. https://doi.org/10.1111/j.1399-6576.2006.01116.x

10. Liu YY, Yeh CN, Lee HL, et al. Local anesthesia with ropivacaine for patients undergoing laparoscopic cholecystectomy. World J Gastroenterol. 2009;15:2376. https://doi.org/10.3748/wjg.15.2376

11. Hilvering B, Draaisma W, Van der Bilt J, Valk R, Kofman $\mathrm{K}$, Consten $\mathrm{E}$. Randomized clinical trial of combined preincisional infiltration and intraperitoneal instillation of levobupivacaine for postoperative pain after laparoscopic cholecystectomy. Br J Surg. 2011;98:784-9. https://doi.org/10.1002/bjs.7435

12. Gurusamy KS, Nagendran M, Guerrini GP, Toon CD, Zinnuroglu M, Davidson BR. Intraperitoneal local ana- esthetic instillation versus no intraperitoneal local anaesthetic instillation for laparoscopic cholecystectomy. Cochrane Database Syst Rev. 2014;13:CD007337. https://doi.org/10.1002/14651858.CD007337.pub3

13. Ross SB, Mangar D, Karlnoski R, et al. Laparo-endoscopic single-site (LESS) cholecystectomy with epidural vs. general anesthesia. Surg Endosc. 2013;27:1810-9. https://doi.org/10.1007/s00464-012-2667-8

14. Naja MZ, Ziade MF, Lönnqvist PA. General anesthesia combined with bilateral paravertebral blockade (T5-6) vs. general anesthesia for laparoscopic cholecystectomy: a prospective, randomized clinical trial. Eur J Anaesthesiol. 2004;2:489-95.

15. Naja ZM, El-Rajab M, Ziade F, Al-Tannir M, Itani T. Preoperative vs. postoperative bilateral paravertebral blocks for laparoscopic cholecystectomy: a prospective randomized clinical trial. Pain Pract. 2011;11:509-15. https://doi.org/10.1111/j.1533-2500.2011.00447.x

16. Forero M, Adhikary SD, Lopez H, Tsui C, Chin KJ. The erector spinae plane block: a novel analgesic technique in thoracic neuropathic pain. Reg Anesth Pain Med. 2016;41:621-7. https://doi.org/10.1097/AAP.0000000000000451

17. Chin, KJ, Adhikary S, Sarwani N, Forero M. The analgesic efficacy of pre-operative bilateral erector spinae plane (ESP) blocks in patients having ventral hernia repair. Anaesthesia. 2017;72:452-60. https://doi.org/10.1111/anae.13814

18. Adhikary SD, Bernard S, Lopez H, Chin KJ. Erector spinae plane block versus retrolaminar block: A magnetic resonance imaging and anatomical study. Reg Anesth Pain Med. 2018;43:756-62. https://doi.org/10.1097/AAP.0000000000000798

19. Bonvinci D, Tagliapietra L, Giacomazzi A, Pizzirani E. Bilateral ultrasound-guided erector spinae plane blocks in breast cancer and reconstruction surgery. J Clin Anesth. 2017;44:13-4.

20. Chin KJ, Malhas L, Perlas A. The erector spinae plane block provides visceral abdominal analgesia in bariatric surgery: a report of 3 cases. Reg Anesth Pain Med. 2017;42:372-6. https://doi.org/10.1097/AAP.0000000000000581

21. Donatsky AM, Bjerrum F, Gögenur I. Surgical techniques to minimize shoulder pain after laparoscopic cholecystectomy. A systematic review. Surg Endosc. 2013;27:2275-82. https://doi.org/10.1007/s00464-012-2759-5 